\title{
A study of Street Children in Kaduna Metropolis, Nigeria.
}

\author{
Abari, Christopher Azaager; Audu, Demsy Terwase \\ Department of Sociology, Faculty of Social Sciences, University of Jos, Jos-Nigeria. \\ Department of Sociology, Faculty of Social Sciences, University of Calabar, Calabar-Nigeria.
}

\begin{abstract}
Social, political, familial, religious and economic forces, all tied to poverty have continued to push children to the streets of urban centres in Third World countries, especially Africa and particularly, Nigerian cities. The study adopted the social survey method. Furthermore, purposive sampling technique was used in selecting heterogeneous sample of eighty (80) street children in Kaduna metropolis. Findings indicated that these children survive under hazardous circumstances as they are victims of material and social-psychological deprivation both from the home front and the society. Many of these children use the street corners as their homes and worst still; they are denied formal education, a very fundamental factor that will change their situation. The study is therefore an attempt to expose the problem and suggest the way forward, for the future of these children in particular, and society at large.
\end{abstract}

Keywords: street children, poverty; almajiri; delinquency.

\section{Background To The Problem}

The need for every child to grow up in a favourable environment that will guarantee the realization of his/her full potential can not to be over-emphasized. In this regard, there has been a deeply entrenched concern for over-all well-being of children to be bound up extricably with their parents, family and community that they live and grow.

The issue of proper child training and development has also been clearly articulated by Ekpe and Mamah (1997), Amali and Ojogbane (2004) and Kopoka (2000). To these scholars, traditional Africa society was characterized by proper establishment of families and family functions were patterned by path-ways, governed by mores and reinforced by moral code for proper child socialization and upbringing. The above scholars report further that community opinion and spirit governed the behaviour of parents in terms of child rearing practices and so parents tended to conform to the standard so as to avoid the sanctions from the community. To these scholars, these expectations were taught and readily adhered to and transmitted through oral tradition by elders.

Children were also highly treasured and they were protected from abuse/neglect as they were believed to be gifts from the creator of humanity. The scholars conclude that the importance attached to children has been responsible for many cases of divorce/separation in circumstances of childlessness not just in Nigeria but Africa as a whole both in traditional and contemporary times. For instance, Kopoka (2000) reports that the baby was seen as belonging to the entire lineage, clan or extended family and so it was the entire responsibility of all these groups to ensure its safety and proper upbringing. Kopoka (2000) further state that in East Africa, a child was normally a member of a community and could not be separated from it. As such, the child was educated and socialized by the community for membership of the community and that adoption was not common as fostering of children by the extended families was the common practice, hence there was no need for orphanages. For Amali and Ojogbane (2004) and Kopoka (2000), children were initiated into the activities of their parents/family which they were expected to be doing throughout their adult life. This was as such a real social security for children and it further enable children to help themselves and also prevent them from unemployment which to a large extent never existed in traditional African setting.

The belief in the fundamental human rights, dignity and worth of human beings as well as the internationally accepted principle that mankind owe to children are issues of utmost concern to both Nigeria and the international communities. A clear demonstration to this effect is the inclusion of the rights and welfare of children in both the Social Development Policy of Nigeria (1989) as well as in the constitution of the Federal Republic of Nigeria. In the same way, there are several international conventions on the rights of children which direct governments to protect children below eighteen years from performing hazardous work, any work that can interfere with their right or education and general economic exploitation. For instance, the International Labour Organization (ILO) has passed conventions on child labour to protect the right of children below the age of fifteen years from employment in any economic sector. In the same way, the entire international community forbids dangerous or harmful employment in areas like prostitution, combat, mining, pornography among others to all children below eighteen (18) years. Similarly, the UNICEF (1985) report exposes the fact that the problem 
of street children is a major issue and if the trend continues, it could pose a big threat on urban civilization particularly in developing countries.

Lamentably enough, the researchers have observed that many children are deserting their families and using the street as their source of livelihood and shelter. Nigerian cities like Lagos, Ibadan, Kano, Port Harcourt, Calabar and Kaduna - the capital of the defunct Northern region and even Abuja - the nation's capital are all witnessing the high prevalence of the problem of street children. This is child abuse and neglect because during childhood, children are supposed to enjoy love, care and overall protection from parents, but this is not the case with the street children in Nigeria.

Worst still, living on the street has several social, physical, psychological and health hazards or consequences associated with it (UNICEF 1985). The study is therefore an attempt to investigate the fundamental causes of this fast emerging social problem of street children in Nigeria's urban centres using the Kaduna metropolis experience. The problem of street children in the society has also attracted the attention of the general public, social critics, mass media, and researchers alike. For instance, Wilmot (2008) laments that:

In every city across the nation, hordes of children who should be in school flood the streets selling cheap goods manufactured in China, newspapers and sometimes their bodies. Many have no parents because of premature deaths due to malnutrition or disease and others have parents who cannot feed, cloth, school or house them. When they complete their day selling in the streets, they may have to find a place to sleep there also.

The situation in Kaduna clearly agrees with the above assertion by Wilmot. On a daily basis, children below 18 years get involved in hawking items like assorted soft/juice drinks, sweets, biscuits, pure water, cookies, gala, plantain chips, bread, cashew nuts and groundnuts. Other items they also hawk include small flannels, handkerchiefs, belts, electrical appliances, mobile phones, recharge cards, mobile phone lines, newspapers, magazines among several other products. In Abuja, areas like Wuse Zone 4 at Sheraton Hotels and Towers Junction and Garki II near Rita Rolly Club House, several young girls hang around waiting for adult patronisers of their commercial sex business right on the streets at night and at very odd hours. The same pattern of prostitution also exists in Jos where young girls hang at Hill Station Junction and places like West of Mines Junction every evening waiting for men to pick them.

The general public and concerned individuals including the researchers are horrified and worried at the hazardous nature and harsh conditions that these children are exposed to in their quest for survival. We are also worried about the exploitation of their labour by their guardians/parents and the future of these children. The activities that these children are involved in also complicate not only their health but many of them live at the mercy of some people that can take their lives for rituals. These children also have a tendency to frequently run into problems with either themselves, members of the public as well as the law enforcement agencies. This results from their attempt to survive by all means including through stealing, cheating and the likes. Thus, many people treat them with contempt and as law offenders. In this way, they do not receive any sympathy from such adults. Apart from this group of people (adults), there are other people that see these children as being victims of circumstances, so this group seems to be more sympathetic with the plight of these children. What is however very fundamental inspite of this attitudinal divide from the members of the public is the seeming consensus view that the problem of street children is as a result of disequilibrated mechanisms/forces with some or several subsystems of the social system.

\section{Objectives Of The Study}

The research is an attempt to explore the problem of street children in Nigerian cities. Specifically it has the following objectives:

- To investigate the fundamental causes of street children

- To ascertain the attitude of parents/guardians to their street children.

- To determine the public perception towards the problem of street children in the society.

- To find out the socio-economic background of the parents/guardians of the street children.

- $\quad$ To proffer remedies that will control the problem of street children in Nigeria.

\section{Conceptual Clarification And Literature Review On The Problem Of Street Children}

Most of the available literature on street children as it relates to Africa indicates that the problem is not traditionally inherent with the African way of life. The problem is thus associated with the contact between Africa, including other developing parts of the world with the West through western education, free market economy and rapid socio-economic and political changes which have influenced government policies that invariably affect the other social sub-systems of the society like family, education, economy and the general community itself.

For instance Liban Oromia; an Ethiopian opinion leader supports the above position that street children are victims of the misguided western system of education imposed on Africa as something good without 
question and so if not followed with job opportunities, it breeds street kids as there were no street kids in rural Africa (BBC News, June 9, 2006).

The above argument is wholesomely shared by Kopoka (2000) that street children are products of free market economy where policies like structural adjustment programmes have persistently impoverished several families; and education now emphasizes white collar jobs, which are also non-existent. Many families are thus going through a lot of instability and breakages leaving the children to survive on their own. At the community level, today's children are the responsibility of their parents not the community thus entrenching individualism as against communalism in the society. Wilmot (2007) on the other hand shares a different opinion that:

The ills of Africa do not result from a curse by God, Satan or natural disaster. While European leaders steal from others to enrich their countries, Africans steal from their people to make Europe even more rich and powerful. Instead of murdering foreign enemies, African leaders slaughter their own citizens justifying the racism of their conquerors (Wilmot 2007:2).

The academic guru (Wilmot) would rather dismiss the argument that it is Western education that breeds poverty with its attendant consequences on child abuse/neglect, homelessness, famine including street children. He attributes these social vices to corrupt leadership problem in Africa that:

The billions secreted in foreign accounts by African leaders is a colossal loss for the continent's impoverished population. It could have been used to build industry, schools, hospitals, roads, railways, houses and to produce food necessary to make famine a thing of the past as leaders have done in parts of Asia (Wilmot 2007:4).

Wilmot therefore blames the problem(s) on the African leaders with the assistance from Western countries that have provided enabling ground for African leaders to continue to decapitalise Africa through money laundering. Consequently, as clarified further by Wilmot (2007:6) that:

Emphasis on money laundering tends to be concentrated on funds for terrorism and drugs forgetting that corrupt African leaders have killed more of their own people than Al-Qeda have killed Americans and Europeans.

Wilmot has as such elaborated enough to show that destitute children are products of a country or region that has been bankrupted by corrupt and irresponsible leadership. He opines further that children that are supposed to be insurance against the vagaries of the future are however taken by some parents as burdens to be overcome due to poverty. He elaborates further that the suffering begins on the day of their child births when poor parents have to source for money to meet their immediate demands especially in Nigeria.

Irrespective of whether or not the causes of street children in Africa can be traced to internal or external sources, what is fundamentally certain is that it is a Third World problem in general and African problem in particular. For instance in the Democratic Republic of Congo (DRC), street children are called "maineanx" or "sparrows"; in Kenya, they are called "chokora" and in Tanzania, they are called "watoto wa mitaani" (BBC News, June 9, 2006). Another fundamental issue of consensus is that the problem is another dimension for child abuse which has equally attracted global attention.

For instance, Reau d' Echanges dis projects des Rues Programmes enfavaveur des Enfants des Rues (i.e. Network of Exchanges and Programmes to help Street children (REPER) in their study conducted in year 2000 identified and classified the causes of street children into family, social, economic, political and others.

The researchers are of the view that family causes include child abandonment, children who get orphaned as a result of war or HIV/AIDS, victims of rape, children of mentally ill, children who have been thrown out of the house after misbehaving etc. The social factors they argue could be children who run away from home when they later discover that their mother is a prostitute, their father a thief etc so they separate from them because of such shameful acts. Sometimes, some handicapped children could be forced to beg or used as beggar assistants. Some of these children may find this act humiliating and will prefer to take to the street to find alternative survival strategies. They conclude that: economic causes have to do with famine, draught, child workers and those whose parents are incapable of sustaining them. Political causes on the other hand have to do with children who have fled from war massacre, boarder closures and end up on the street among several other factors.

The BBC News magazine conducted a survey in June 2006 on the causes of street children in Africa and below is some of the responses across the Continent: Daniel Bassah from Ghana responded that street children result from rural urban drift. Onubot-Pepple Stella of Nigeria held that high level of poverty and bad governance are causes of street children in some countries while in others, it is caused by persistent wars. Ernest Chi, an American based Sierra-Leonian shares the view that street children are victim of mistreatment. Another Sierra-Leonean, Sigmund Wilson responded that street children are victims of wars perpetuated by politicians who insist on having firm grip of power at all cost and engage in mismanagement of national wealth. This 
position was also canvassed in that study by another Nigerian; Ashipa James Olashupo that leaders loot money that should have gone into development of educational institutions, as well as other cultural practices like polygamy and lack of family planning.

In another similar interview conducted by Newswatch Magazine in November 1991, causes of street children were discovered to include deception about better economic and living opportunities in the city, abandonment, truancy, family hostility, broken homes etc. This last point has been corroborated by Foxcroft (2007) that majority of children in Akwa Ibom are on the streets because they are orphans whose step mothers brand them as "witches" or "wizards" and cast them on the streets.

Ebigbo (2003) on the other hand believes that religious practices in northern Nigeria tend to push children on the streets (almajaris) as a strict form of child upbringing to acquire religious training from their Islamic instructors. On another account, the scholar reports further that some parents also send their children (daughters) on the street to make enough money for their mothers to buy household goods for them when they marry.

Similarly, Wazed (2007) discovered in Dhaka, Bangladesh that street children can be attributed to both push and pull factors that are all related to poverty. Factors like polygamy, natural calamities, unemployment, patriarchy etc were the major causes of the problem. In the same way Campbell and Ntsabane (1995) also discovered that poverty, parental neglect and harassment at the home front were the major factors that account for children taking to the street in Gaborone, Botsawa.

From the foregoing elaboration, we can clearly attest to the fact that the problem of street children is rampant in Third World countries but the rate is particularly higher in Africa. In Nigeria, the situation has taken a high toll that all the metropolitan cities now harbour numerous street children. The available literature on the causes of street children attribute the problem to religious, political, cultural, familial, corruption and economic factors.

\section{Methodology}

The social survey research design was adopted in order to investigate the factors that push children to the streets in urban centres. This design was adopted because of its strength in external validity and its advantage for the generalization of findings to a wider population and especially because of the heterogeneity of the population (Barbie, 2010; Ibanga, 1992). The population of the study comprised of all the male and female children below 18 years who have taken to the streets of Kaduna metropolis and whose survival is dependent on the proceeds that they generate daily either through begging or other economic activities that they engage in. In view of limited resources and time constraint, it was not possible and also not necessary for the researchers to study the entire street children whose total population appear to run into several thousands. Kaduna city was therefore divided into different clusters. Out of these areas, the researchers purposively limited the study to four (4) areas namely: Kawo, Kaduna Central, Barnawa and Sabo. The selection was purely based on the fact that these areas have the highest concentration of street children in Kaduna. The non-probability sampling technique was further employed as a result of the absence of the total number of street children in Kaduna and because some of the children approach declined participation in the study. Hence, 20 street children who were willing to participate in the study were purposively selected in each of the four areas (i.e. Kawo 20; Kaduna Central 20; Barnawa 20; and Sabo 20; thus comprising 40 boys and 40 girls, totalling 80. Furthermore, 32 parents/guardians of the children were purposively selected in order to validate some of the claims of the street children for why they were on the street.

\section{Socio-Demographic Characteristics of the Respondents}

\section{Result And Discussion}

Street children socio-demographic characteristics were sought. The study had an equal representation of both genders. It was found that all the street children were below 18 years. Furthermore, the study had an equal representation in terms of religion (50\% Christian and Muslim - the two major religions in Nigeria). All the children (40) from the Moslem group had no secondary education at all while few Christian boys and girls (10) representing $12.5 \%$ attempted secondary education. This means that most of these children were not educated above primary level as only $12.5 \%$ of the children were in secondary school. They all presented a situation that revealed that their parents were not wealthy people. $47.5 \%$ of the Muslim street children were from polygamous homes, while majority of the street children from Christian homes were of monogamous homes.

\section{Street Children's Daily Economic Activities}

The children engage in various activities ranging from shoe shining, begging, hawking of wares like handkerchiefs, yoghurts, assorted drinks, boxers, recharge cards, cigarettes, lighters, groundnuts, pears, oranges, mangoes etc. Others are vendors of magazines and newspapers while others are porters and bus conductors. 
Others, particularly the boys also survive through car washing, other menial dirty jobs and scavenging. Consequently, 25\% of the children aged $16-17$ years had spent about 10 years as street children. Majority of the children (65\%) took to the street at the age of 6-8 years and also indicated the age of entry as around 6 years for the boys especially the beggars, the same age applies to the female hawkers who started trading early enough. It was also found that many of the beggars and shoe shiners were of the Islamic faith that had left their parents in distant towns and states away from Kaduna and were brought up by their religious teachers. On closing from each Quranic lessons, they take to the street as water vendors, shoe shiners and carryout other menial jobs that came their way. Many of such children end-up sleeping on the street in motor parks, abandoned/uncompleted buildings or broken down vehicles, after their daily business but all the girls indicated that they usually go back to meet their families. $10 \%$ of the street girls were already into child prostitution and further report and remit their proceeds to their guardian.

\section{Usage of Proceeds by Street Children}

Most of the children use the proceeds of their labour to supplement the family income. This clearly attests to the fact that they are from poor family backgrounds. For instance, Moslem beggars who constituted $12.5 \%$ of the respondents must remit their daily proceeds to their Islamic instructors. $25 \%$ of the street girls indicated that their proceeds are given to their family for safe-keeping. These proceeds they claimed are later use for the purchase of valuables for them when they marry. Furthermore, $25 \%$ of the street girls from Christian homes indicated that their proceeds belong to their guardians and they do this business to support the family income after school hours. The remaining $20 \%$ (boys and girls) of street children reported that they control their resources by themselves. It was found that parents/guardians supported and encourage taking to the street, as indicated by majority $(80 \%)$ of the street children.

\section{Reasons for Being on the Street}

Different reasons accounted for why these children were on the street: for example, $10 \%$ of the street children indicated that they were orphans with no one to cater for their needs; $12.5 \%$ blamed their been on the street to hostile family environment, parental neglect, and desire to be independent and broken homes; $20 \%$ attributed it to making earnings for the family; 5\% attributed their situation to adventure, perception of city life, influence of peer groups and $50 \%$ of the street children practising Islam attributed it to religion. Other reasons like not being properly fed by parents/guardians; inability to provide school uniforms and pay school fees. These findings agree with the earlier submission that in whatever angle you look at the problem, the causes are multidimensional and usually cut across, social, familial, religious, political and economic forces. The children especially the Moslems shared the belief that it is only Allah/God that can determine people's destiny so they are very hopeful of succeeding in life even without education. They even sighted examples of many prominent people that they know who were raised to such positions by destiny even though they are illiterate. Some of the children hoped to save and grow up to be businessmen, transporters and some others were still hopeful of going back to school whenever their financial condition becomes more favourable.

\section{Socio-Economic Conditions and Attitudes of Parents/Guardians towards their Street Children}

Majority of the street children attributed their being on the street to parental neglect, family harassment and that their deprivation was particularly poverty driven in nature. This was validated from the interview with parents as most of them attributed their inability to cater for their children to hard times. Many indicated that they were unemployed and others reported to have retired from public service and yet to receive their retirement benefits. Some $(9.37 \%)$ of the parents also attributed their poor economic conditions to ill-health, which made it difficult for them to effectively provide for the upkeep of their families. These findings validate the claims of the street children that material deprivation is the reason for their being on the streets. Majority of the parents of these street children had no formal education and hence their inability to get prestigious jobs that guaranteed constant income to cater for their families. Besides, their understanding of what constitutes child abuse and neglect is also limited with their poor educational background. Some of the parents attributed their children's been on the street to peer influence and the gangster subculture. On the whole, majority $(75 \%)$ of the parents/guardians reported that they would not support their children taking to the street especially if they had their way, while some of the parents hoped to send their children to school or better vocations as soon as their financial situation improves. Those parents/guardians that were Moslems however did not seem to look at street children's way of life as abnormal as such were not in a hurry to evolve alternative living strategies for the children. 


\section{Conclusion}

The study has unveiled the predisposing factors that account for the rising wave of street children in Africa and Nigeria using the Kaduna metropolis experience. On the basis of our findings, we can draw the following deductions:

- Most of these children are from poor homes with low socio-economic backgrounds.

- Majority of the children use the proceeds of this activity for the upkeep of their families.

- Material deprivation and other abuses from the home front are major factors that push the children to the street.

- Some of the children at that tender age get cut off from their families completely.

- Most of these children and their parents/guardians have little or no formal education. Thus their chances of breaking out of their culture of poverty appear to be very slim.

- Finally, the state has continued to withdrawal its attention from providing social welfare to citizens, particularly family and child welfare, thus escalating the menace of street children in the society.

Conclusively, the problem of street children has to be collectively addressed by the family, policy makers, religious teachers, educators and social scientists alike (as parents of street children turn away researchers), individuals, governmental and non-governmental organizations. We will therefore conclude with the words of Wilmot (2007:35) that:

Like other peoples of the world, Nigerians have the right to life, liberty and happiness. But they also need jobs, food, housing, healthcare, education, stability, a secure future for their children.

If these things are not put in place, such children will develop into future armed robbers, political thugs and other desperadoes that will make Nigeria hell on earth.

\section{References}

[1]. Amali, A.O. and Ojogbane, V.T. (2004). "The child, family and value inculcation in Idoma Land", Journal of Development,(2), 236-237.

[2]. Awotunde, P.O. \& Ogodulunwa, C.A. (2004). Research methods in education. Jos: Fab Anieh Nig. Ltd.

[3]. Babbie, E. (2010). The practice of social research. New York: Wards Worth.

[4]. BBC News Magazine, June 9, 2006

[5]. Campbell, K.E. and Ntsabane, T. (1995). Street Children in Garborone, Botswana: Causes and Policy Implications. Dept. of Demography and Sociology, University of Botswana.

[6]. Ebigbo P.O. (2003). Street Children: The core of child abuse and neglect in Nigeria. Nsukka: University of Nigeria Press.

[7]. Ekpe, C.P. and Mamah, S.C. (1997). Social work in Nigeria: A colonial heritage. Enugu: Uniks Oriental Prints.

[8]. Federal Republic of Nigeria (1989). Social development policy. Lagos: Federal Ministry of Information.

[9]. Foxcroft, G. (2003). Supporting Victims of Witchcraft Abuse and Children in Nigeria. Paper Presented during Stepping Stone Workshop in Uyo in September.

[10]. Ibanga, U.A. (1992). Statistics for social sciences. Jos: Centre for Development Studies, University of Jos.

[11]. Kopoka, A.P. (2000). The Problem of Street Children in Africa: An Ignored Tragedy. Being a paper presented at International Conference on Street Children and Street Children's Health in East Africa at Dar Es Salaam, Tanzania on April 19-21.

[12]. REPER (2000). Street children. Sierra-Leone: REPER Press.

[13]. UNICEF (1985). The state of world's children. Oxford: Oxford University Press.

[14]. Wazed, S. (2007). An Analysis of Life Experiences of Street Children in Bangladesh. Unpublished M.Sc. Thesis in Comparative Social Work. Bangladesh, University of Dhaka.

[15]. Wilmot, P.O. (2007). Selected lectures: 2004-2007. Jos: University of Jos Press.

[16]. Wilmot, P. (2008). "The Challenge of Destitution in Northern Nigeria". A Talk Delivered at the Transcorp Hilton Hotel, Abuja on April 20, 2008 under the Auspices of Sardauna Magazine. 